\title{
Scanning electron Microscopic Studies on the Microvascular System of the Spleen in the Rat, Cat, Dog, Pig, Horse and Cow.
}

\author{
Azusa SEKI, and Mitsuo ABE ${ }^{1)}$ \\ Department of Veterinary Radiology, and 'Veterinary Anatomy, The College of Dairying, Ebetsu, Hokkaido 069-01, \\ Japan
}

(Received 22 December 1983/Accepted 17 January 1984)

\begin{abstract}
Structural details of the sheathed artery, arterial capillary and splenic sinus of the spleen were comparative-morphologically studied by scanning and transmission electron microscopy in the rat, cat, dog, pig, horse and cow. The network of the sheathed artery contained platelets and erythrocytes, but no other blood cells, except for macrophages in the dog. Slits with a diameter of 1-3 $\mu \mathrm{m}$ were found between the endothelial cells in all species except for the dog. The terminal portions of the arterial capillaries were sack-shaped in the rat, dog, pig and horse, and were funnel-shaped in the cow. These portions had small pores communicating with the cordal spaces. Some arterial capillaries opened into the splenic cords in the rat, but opened directly into the sinuses in the others. The endothelial cells of the sinus were rod-shaped in the rat, dog and cow, but flat stellate-shaped in the cat and horse, and in the pig they were of both types. The walls of the sinus had slits through which blood cells and macrophages passed from the sinusal lumen to the cordal space or vice versa. Reticular cells toughed on the outside of the endothelial cells of the sinus.-KEY WORDS: animal spleen, arterial capillary, sheathed artery, splenic sinus.
\end{abstract}

Jpn. J.Vet. Sci. 47(2): 237-249, 1985

Histological studies on the structure of the spleen have been made since the 19th century [2] and revealed that the spleen plays a role as a complex filter interposed in the blood stream. The vascular system in the spleen has been well studied in man and experimental animals [5, 7, 16, 18, 19, 22, 34, 42, 45], but only a few in the domestic animals, especially using electron microscope $[30,42$, 48].

Schweigger-Seidel [33] reported that the sheathed artery was a capillary surrounded by the sheath consisted of adventitial cells. The structure of the sheath has been discussed by several workers $[17,18,36]$. However, some species, such as mouse, rat and rabbit, lack sheathed arteries [32, 34].

Arterial capillaries known as "terminal capillaries" run into the splenic cords. The cordal reticular cells sent their processes to reach the arterial capillary. It has been discussed by many investigators $[4,16,21,35$, 44] whether the terminal of the arterial capil- lary opens into the splenic cords or connects with splenic sinus. There are three interpretations on the termination of the arterial capillary; the first is the "open circulation" where the terminal opens into the splenic cords, the second is the "closed circulation" where it connects with sinuses and the third is "divided circulation" where the terminal has both "open and closed circulation"' [8, 32, 42, 47].

The splenic sinus consists of rod-shaped endothelial cells with slits and argyrophilic circumferential (ring) fibers. These structures were first described in the spleen of the dog and human [3, 44]. Whereas, the sinus of cat, pig, horse and cow had not an anastomosing network of venous vessels that were encircled by ring of argyrophilic fibers and rod-shaped endothelial cells. The spleens of these species were classified as "non-sinusal (having primordial vein)" by Snook [34].

In this paper, comparative studies were made on the morphology of the sheathed 
Table 1. Comparison of fine structures of sheathed arteries of cat, dog, pig, horse and cow

\begin{tabular}{|c|c|c|c|c|c|c|c|}
\hline \multirow[b]{2}{*}{ Species } & \multirow{2}{*}{$\begin{array}{l}\text { Diameter of } \\
\text { the sheathed } \\
\text { artery }(\mu \mathrm{m})\end{array}$} & \multicolumn{3}{|c|}{ Endothelial cell } & \multicolumn{3}{|c|}{ Sheath } \\
\hline & & Shape & Slit & $\begin{array}{l}\text { Micro- } \\
\text { filament }\end{array}$ & $\begin{array}{l}\text { Cell } \\
\text { layer }\end{array}$ & $\begin{array}{l}\text { Macro- } \\
\text { phage }\end{array}$ & $\begin{array}{l}\text { Border on } \\
\text { the cord }\end{array}$ \\
\hline Cat & $30-40$ & Rod & + & H & $1-2$ & - & Clear \\
\hline Dog & $30-40$ & Rod & - & H & $2-4$ & + & Unclear \\
\hline Pig & $60-90$ & Rod & + & $H$ & $5-6$ & - & Clear \\
\hline Horse & $40-60$ & Rod & + & H & $2-3$ & - & Clear \\
\hline Cow & $10-20$ & Rod & + & + & $1-2$ & - & Clear \\
\hline
\end{tabular}

Rat spleen lacks sheathed arteries.

artery, arterial capillary and splenic sinus of the rat, cat, dog, pig, horse and cow by scanning and transmission electron microscopy.

\section{MATERIALS AND METHODS}

Spleens from 15 rats, 5 cats, 5 dogs, 21 pigs, 4 horses and 3 cows were used as materials in the present study.

Before slaughter, rats and dogs were anesthetized with sodium pentobarbital solution and cats with chloroform. Pigs, horses and cows were not anesthetized.

The spleens were excised just after slaughter and perfused from the splenic artery with Ringer solution at room temperature, followed by perfusion of $0.5 \%$ glutaraldehyde or $10 \%$ formaldehyde in $0.1 \mathrm{M}$ phosphate buffer at $\mathrm{pH} 7.4$. The outflow of the perfusate was prevented by ligation of blood vessels at the splenic hilus. The organs were immersed in the same fixative for a few hours.

Tissue blocks measuring about $2 \times 2 \times 10$ $\mathrm{mm}$ were dissected out from the spleen in the fixative and fixed further for about $30 \mathrm{hr}$. According to the "modified tannin-osmium" method [29], specimens were impregnated, dehydrated in ascending series of ethanol and transferred to isoamylacetate. They were then freeze-cracked in liquid nitrogen, dried at critical point in liquid $\mathrm{CO}_{2}$, and coated with gold in a vacuum evaporator [38, 39].
Cast specimens were made by injection of resin (MERCOX CL) from the splenic artery, followed by maceration with $15-20 \% \mathrm{NaOH}$ solution. These specimens were observed and photographed with a Hitachi HHS-2R scanning electron microscope under an accelerating voltage of $20 \mathrm{kV}$.

Specimens for transmission electron microscopy were fixed in $2.5 \%$ glutaraldehyde and embedded in epoxy resin (Quetol 812). Ultrathin sections were stained with uranyl acetate and lead citrate. They were examined with a JEM-100S transmission electron microscope under an accelerating voltage of $80 \mathrm{kV}$.

A part of specimens were also embedded in paraffin, sectioned at $4 \mu \mathrm{m}$, stained with hematoxylin-eosin and observed with a light microscope.

\section{RESULTS}

\section{Sheathed artery (Table 1)}

The sheathed artery consisted of the endothelium and the surrounding sheath composed of several layers of reticular cells. The diameter of the sheathed arteries and layers of the sheath were different among the species. The sheath was largest in the pig, rather small in the horse, dog and cat, and smallest in the cow. The rat lacked sheathed arteries. The endothelia of these vessels in the cat, dog, pig, horse and cow were composed of rodshaped cells arranged parallel to the long axis 


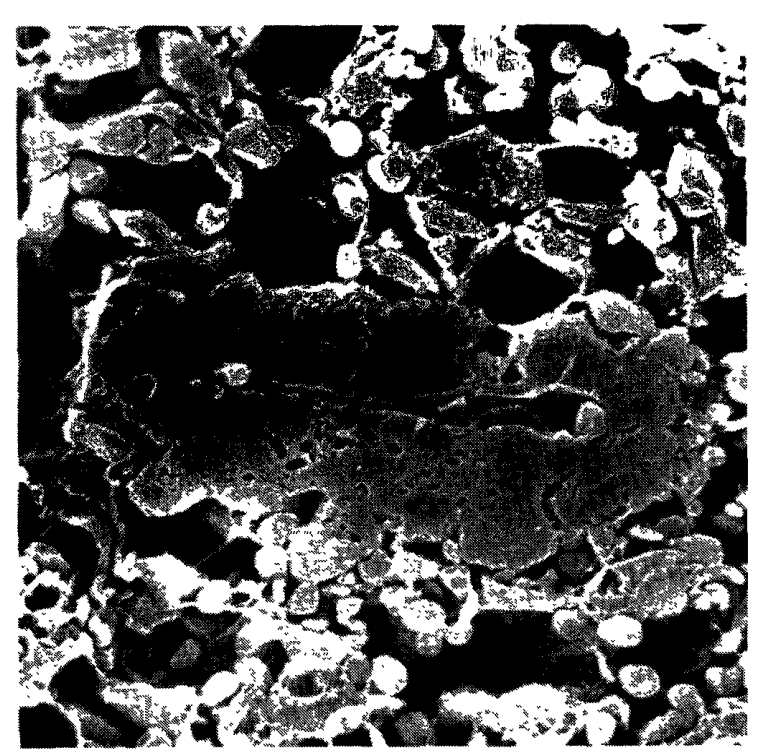

Fig. 1. Sheathed artery (SA) of the cow spleen. A dense sheath consisting of reticular cells is clearly separated from the splenic cords. No macrophages are visible. $\times 1,100$.

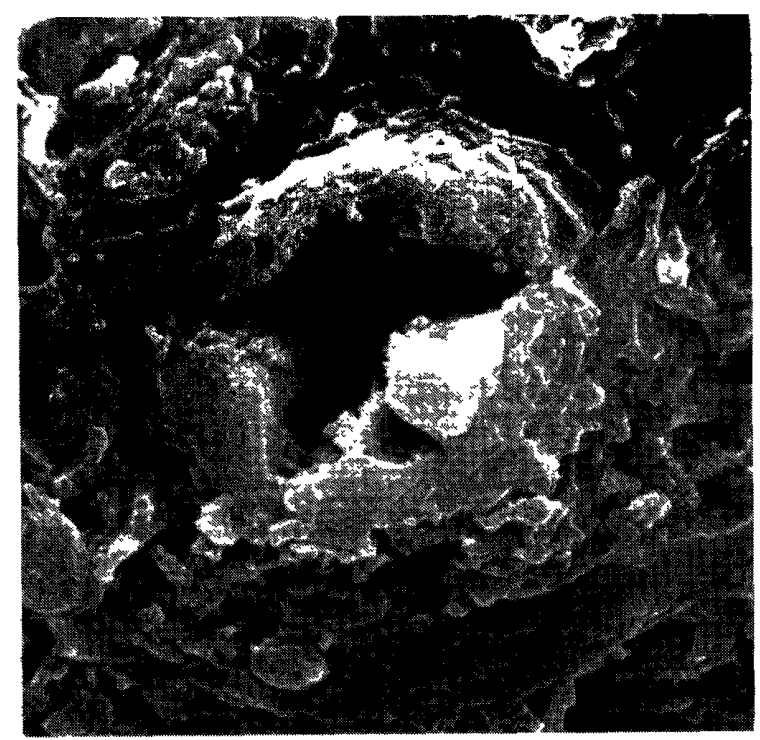

Fig. 3. Sheathed artery of the horse having slits (arrow) in the wall. The endothelium consists of rod- or spindle-shaped cells. $\times 4,500$.

of the vessel, Slits with a diameter of 1-3 $\mu \mathrm{m}$ were found between the endothelial cells in all species except for the dog (Figs. 1-3). Nuclear portion of the rod-shaped endothelial cells of the cat, dog, pig, horse and cow showed ovoidal elevation protruded into the capillary lumen (Fig. 1-4). The cytoplasm of the endothelial cells contained many filaments, which were about $10 \mathrm{~nm}$ in diameter

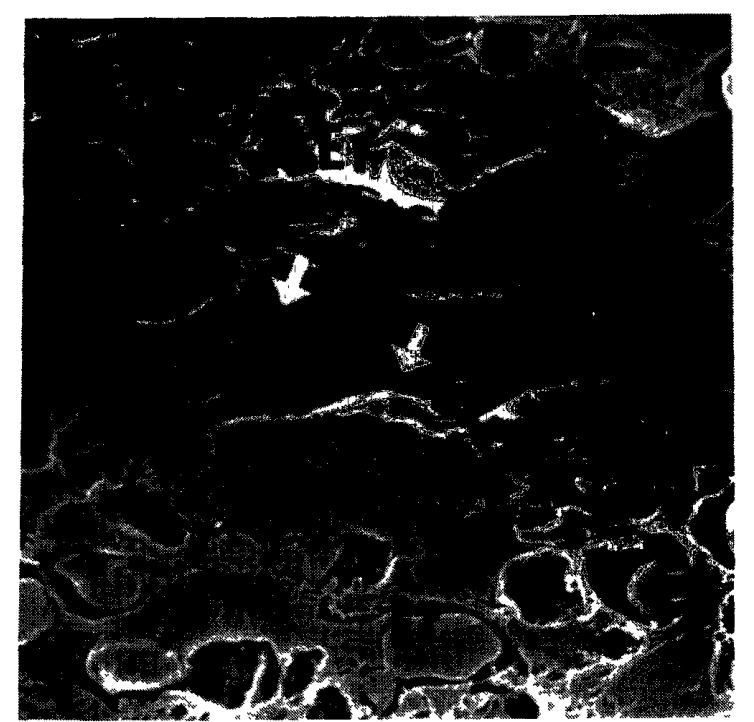

Fig. 2. Sheathed artery of the pig spleen having oval slits (arrows) $1.0 \times 1.5 \mu \mathrm{m}$ in size. The endothelial cells are spindle- or rod-shaped and run along the long axis of the capillary. Reticular cells of the sheath, erythrocytes $(\mathrm{Er})$ and platelets $(\mathrm{P})$ are observed in the reticular network. $\times 2,700$.



Fig. 4. Endothelial cell of the sheathed artery of the pig containing microfilaments and a dense body (arrow). $\times 19,000$.

and of various electron density according to the species (Fig. 4).

The network of the sheathed artery contained platelets and erythrocytes, but no other blood cells, except for macrophages in the dog (Figs. 1-3, 5 and 6). The contour of the sheathed arteries was clearly distinguished by scanning electron microscopy from the splen- 


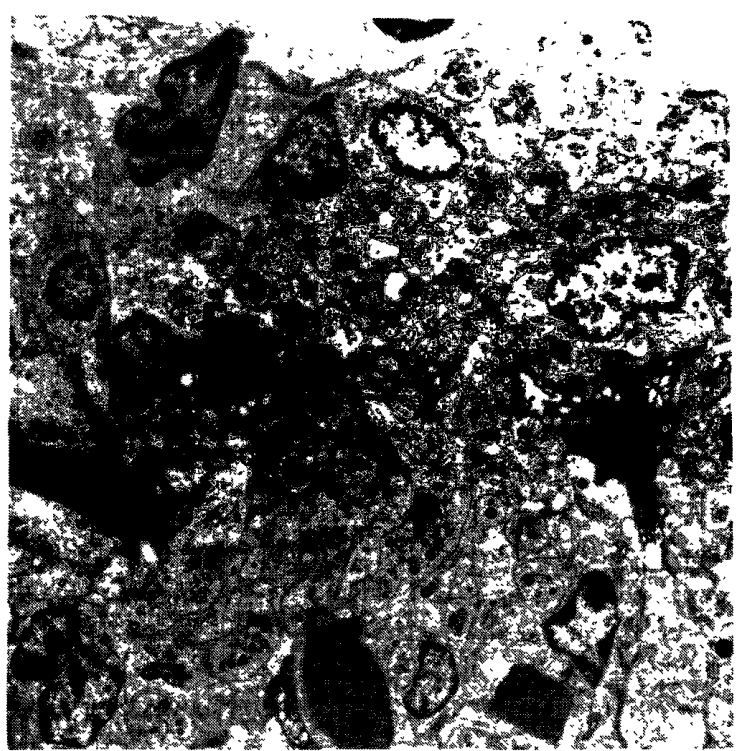

Fig. 5. Arterial sheath of the pig. It consists of reticular cells and reticular fibers forming networks to contain erythrocytes $(\mathrm{Er})$ and platelets $(\mathrm{P})$. The right is cordal side. $\times 1,800$.

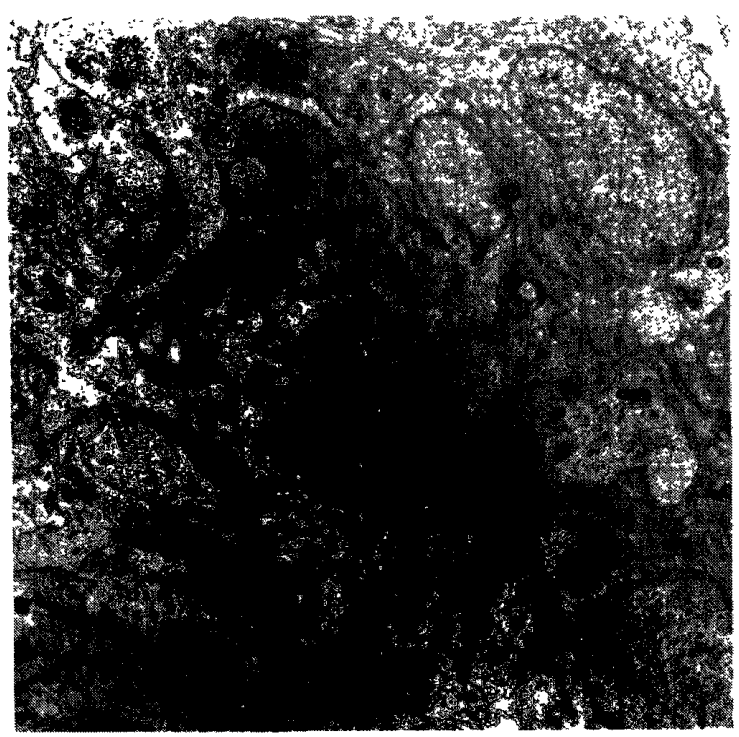

Fig. 6. Arterial sheath of the dog. Macrophages (Mc) are observed in the sheath. The right is cordal side. $\times 2,700$.

Table 2. Comparison of fine structures of arterial capillaries of rat, dog, pig, horse and cow

\begin{tabular}{|c|c|c|c|c|c|}
\hline \multirow{2}{*}{ Species ${ }^{\text {a) }}$} & \multicolumn{2}{|c|}{ Endothelial cell } & \multicolumn{2}{|c|}{ Terminal portion } & \multirow{2}{*}{$\begin{array}{l}\text { Circulation } \\
\text { system }\end{array}$} \\
\hline & $\begin{array}{l}\text { Elevation of the } \\
\text { nuclear portion }\end{array}$ & Slit & Shape & Slit & \\
\hline Rat & Low & $\begin{array}{l}\text { Presence or } \\
\text { absence }\end{array}$ & Sack & Visible & $\begin{array}{l}\text { Open or } \\
\text { close }\end{array}$ \\
\hline Dog & Low & Absence & Sack & Visible & Open \\
\hline Pig & Low & $\begin{array}{l}\text { Presence or } \\
\text { absence }\end{array}$ & Sack & Visible & Open \\
\hline Horse & Low & Absence & Sack & Visible & Open \\
\hline Cow & Low & Absence & Funnel & Visible & Open \\
\hline
\end{tabular}

a) Arterial capillaries were not observed in the cat.

ic cords in the cat, pig, horse and cow (Figs. $1,5,12$ and 17), but not in the dog.

Reticular cells of the sheath had ovoid or irregular nuclei, and contained many mitochondria and rough endoplasmic reticula and a few lysosomes (Figs. 5 and 6). Debris of phagocytized erythrocytes were not found in the reticular cells.

\section{Arterial capillary (Table 2)}

The distal portion of the sheathed artery was continuous with the arterial capillaries. In the cat, the arterial capillary was not recognized by SEM. The nuclear portion of the endothelial cells near the terminal portion were small and did not show an elevation on the surface of the cells. A few villous microprojections were present on the surface of the endothelium. Slits were observed only in the rat and pig between the endothelial cells (Figs. 7 and 8). The reticular cells and their processes were attached on the outside of the wall of the capillary (Fig. 9).

Terminal portions of the arterial capillaries were opened into the reticular meshwork in 


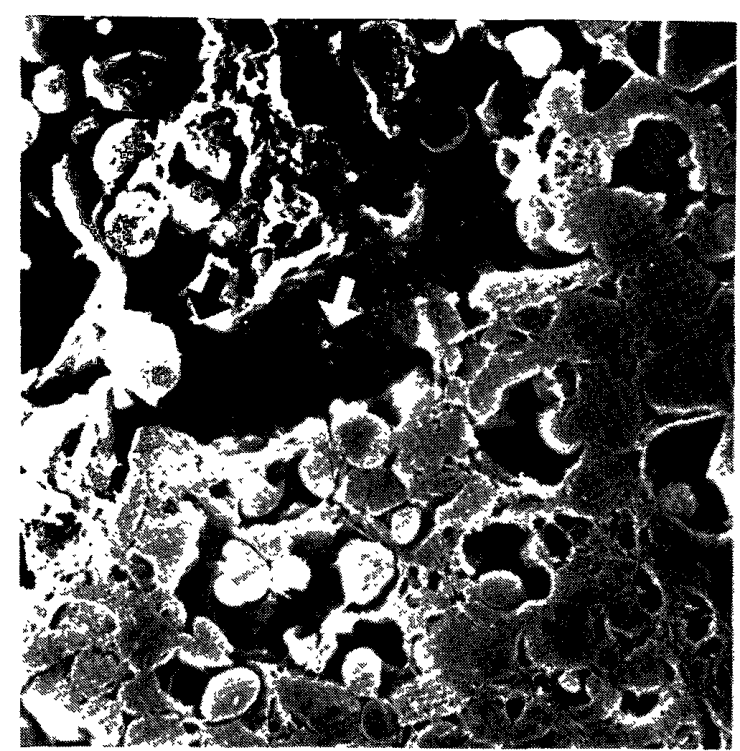

Fig. 7. Arterial capillary of the pig running in the splenic cords. It has some pores (arrows) about $3 \mu \mathrm{m}$ in diameter. The endothelium is smooth, with some microvilli-like projections. The pulp reticular cells are observed to touch on the outside of the endothelium. $\times 1,100$.

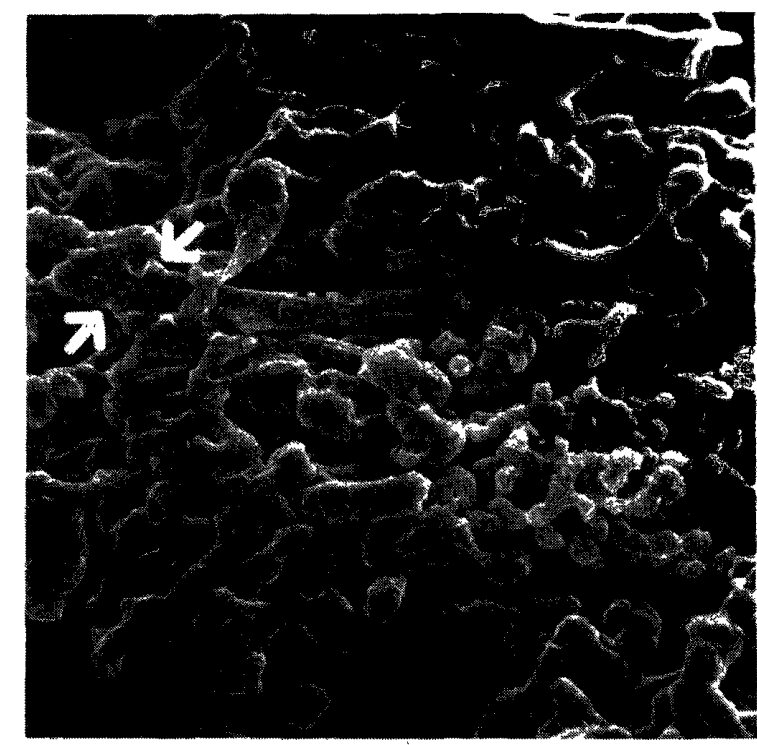

Fig. 8. Cast specimen of the pig. An arterial capillary (AC) runs from the sheathed artery (SA) and ends to be sack-shaped in the splenic cords. Resin leaked out from the sidepores into the splenic cords (arrows). $\times 360$.

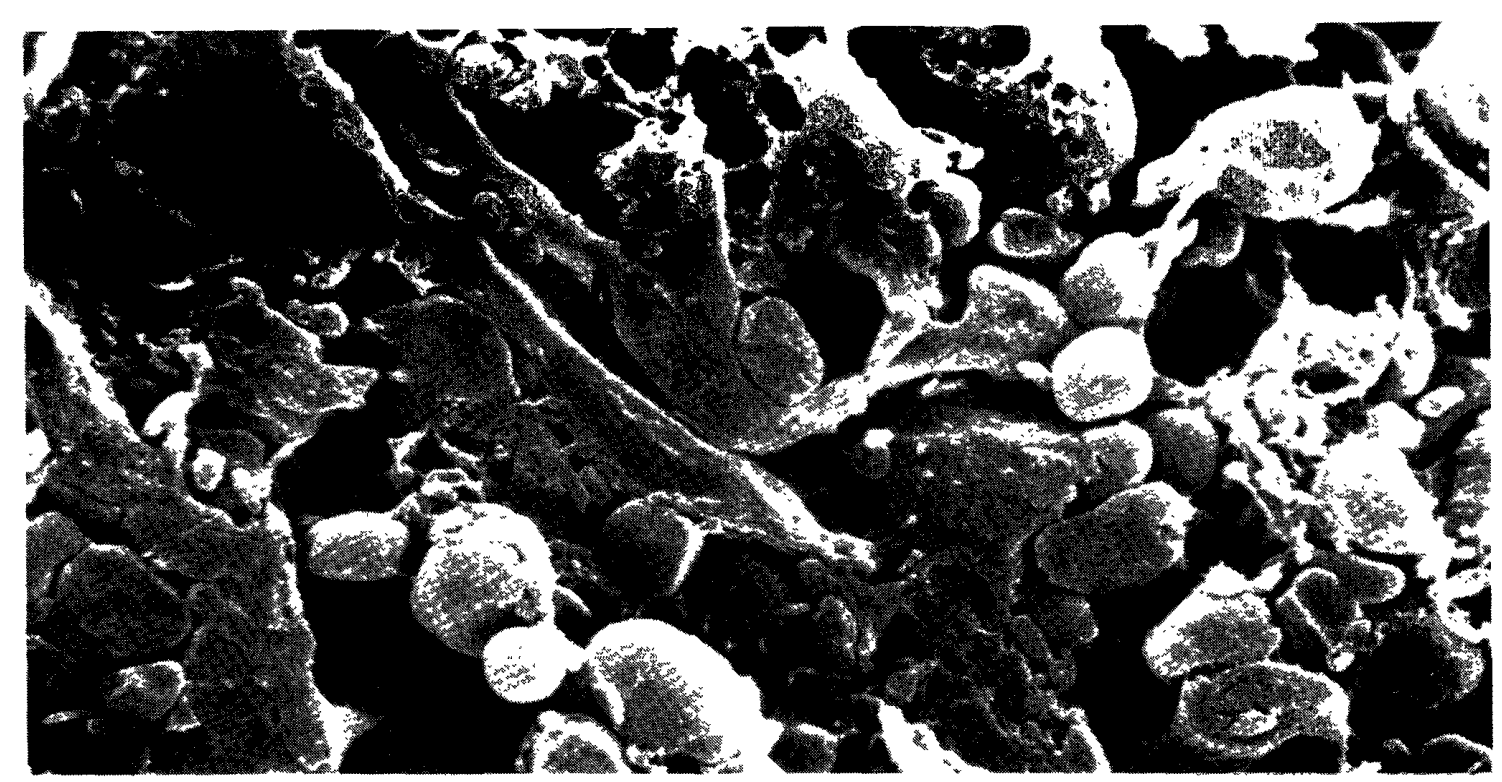

Fig. 9. Arterial capillary (AC) and terminal portion of the cow. The capillary runs straight in the splenic cords and has a funnel-shaped opening. There are some sidepores in the terminal portion. $\times 2,800$.

the dog, pig, horse and cow. They were sackshaped in the rat, dog and horse and funnelshaped in the cow. In the dog, terminal portions ended near the sinus wall and some attached to the sinus wall. In the rat, some were opened into the red pulp and others were connected with the splenic sinus. Terminal portions had small sidepores and endpores, but no valves and sphincters in all the species examined (Figs. 8-11).

\section{Splenic sinus (Table 3)}

The sinuses were wider and shorter in the cat, pig, horse and cow than in the rat and dog. In the rat and dog, the splenic sinus had 


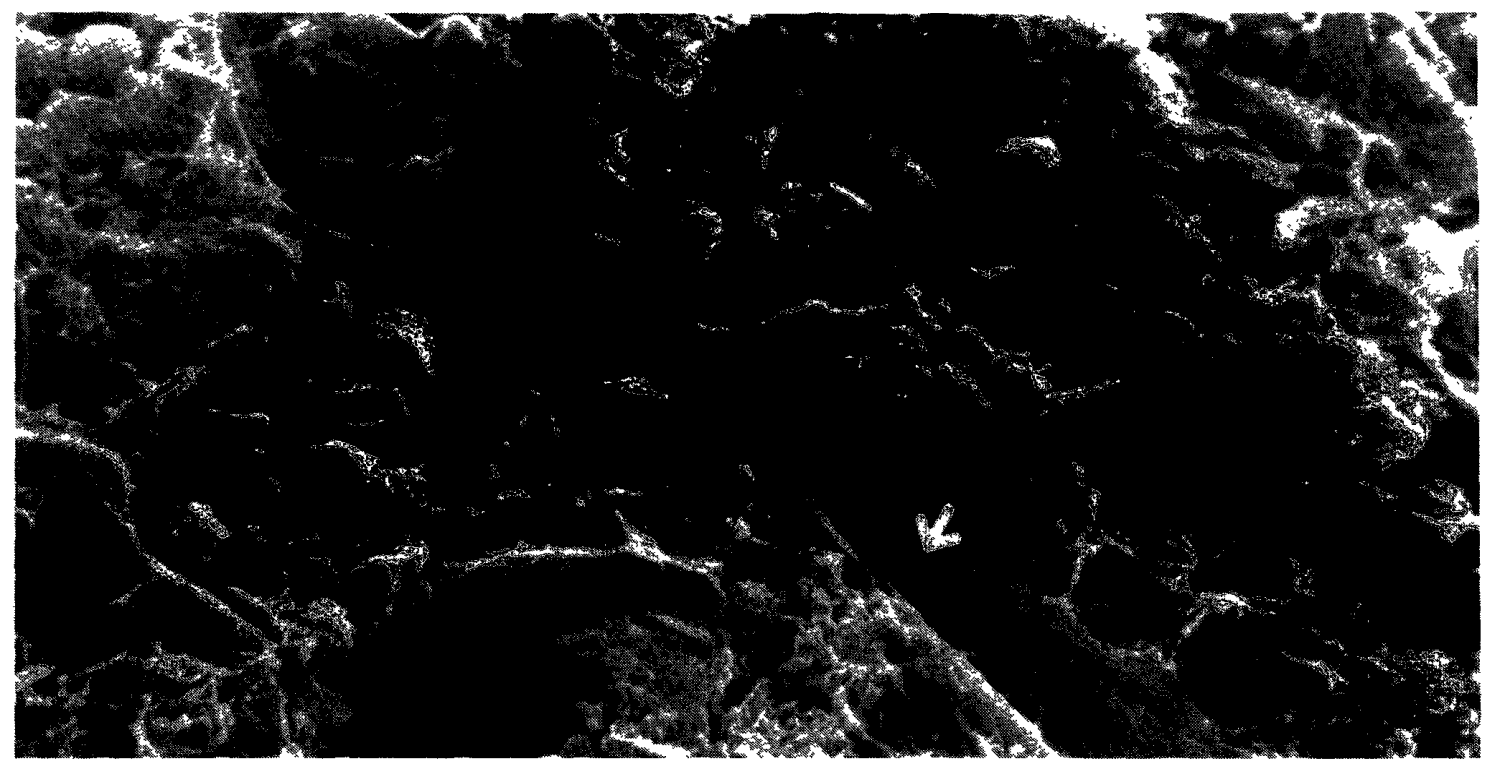

Fig. 10. Arterial capillary of the rat. The capillary (AC) connects directly with the sinus (S). An arrow indicates an anastomosing portion. The capillary has a few small sidepores, but neither valves nor sphincters. $\times 1,800$.

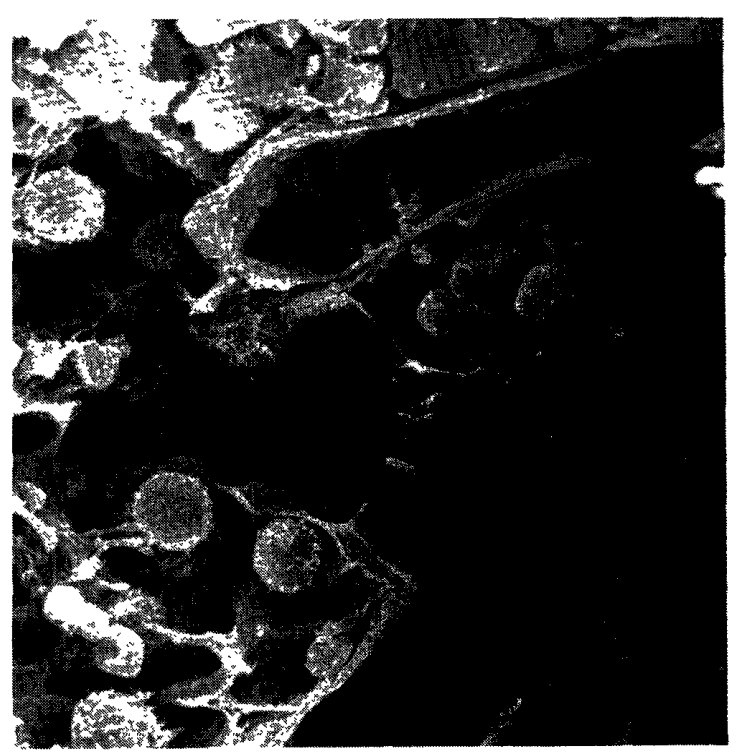

Fig. 11. Arterial capillary of the horse. The endothelium of the capillary protrudes a little into the lumen. Pores (arrows) are observed in the sack-shaped terminal portion. $\times 1,400$.

rod-shaped cells arranged in parallel along the long axis of the sinus to form a lattice-like structure except in the anastomosing areas. The nuclear portions of the cells exhibited ovoid to ball-shaped protuberance protruded into the lumen of the sinus. The neighboring cells were bridged by transverse cytoplasmic processes to leave ovoid or spindle slits be-



Fig. 12. Low power magnification of the horse spleen showing sheathed artery (SA) and sinus (S). The sheath is distinguished clearly from the cords. The area of the sinus is small and that of the splenic cords is large. $\times 250$.

tween them (Figs. 13, 14 and 18). In the cow, endothelial cells arranged more irregularly than in the rat and dog, and had transverse processes sometimes crossed to extend to the outside of the neighboring cells (Figs. 13 and 14). In the splenic sinus of the pig, endothelial cells were divided into two types, 
Table 3. Comparison of fine structures of the splenic sinus of rat. cat. dog. pig. horse and cow

\begin{tabular}{|c|c|c|c|c|c|}
\hline \multirow{3}{*}{ Species } & \multirow{3}{*}{$\begin{array}{l}\text { Size of the } \\
\text { sinus in the } \\
\text { red pulp }\end{array}$} & \multicolumn{3}{|c|}{ Endothelial cell } & \multirow{3}{*}{$\begin{array}{l}\text { Meshwork of re } \\
\text { ticular cell on } \\
\text { the sinus wall }\end{array}$} \\
\hline & & \multirow{2}{*}{ Shape } & \multirow{2}{*}{$\begin{array}{c}\text { Lateral } \\
\text { process }\end{array}$} & \multirow{2}{*}{$\frac{\text { Slit }}{\text { Diameter }(\mu \mathrm{m})}$} & \\
\hline & & & & & \\
\hline Rat & Large & Rod & + & $2-6$ & + \\
\hline Cat & Small & Stellate & - & $4-16$ & + \\
\hline Dog & Large & Rod & + & $1-3$ & + \\
\hline Pig & Small & $\begin{array}{l}\text { Rod or } \\
\text { stellate }\end{array}$ & + or - & $4-7$ & + \\
\hline Horse & Small & Stellate & - & $2-6$ & + \\
\hline Cow & Small & Rod & + & $2-4$ & + \\
\hline
\end{tabular}

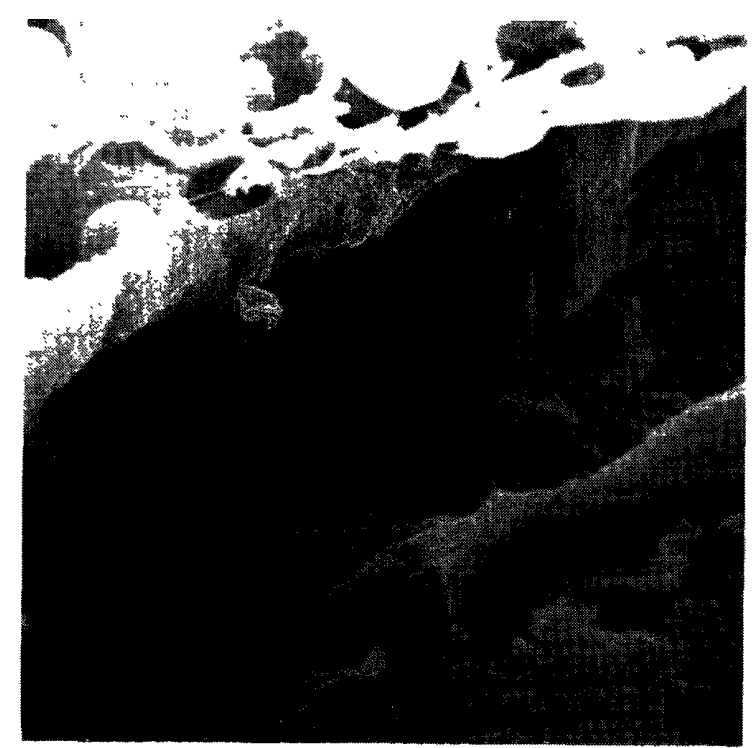

Fig. 13. Sinus of the cow. The endothelial cells are rod-shaped with lateral processes which connect with neighboring endothelial cells to leave small to large slits (arrows). $\times 2,400$.

rod-shaped and stellate-shaped, the latter being the majority of the endothelial cells (Figs. 15 and 16). The splenic sinuses in the cat and horse were short and sometimes showed branchings and anastmoses. The endothelial cells of the cat and horse were stellate-shaped and had spindle-shaped nuclear portions protruded into the lumen. The cytoplasm of the endothelial cells were narrow and long in the cat, but wide and short in the horse (Figs. 12 and 17).

Slits of the sinus of the pig were fewer, larger and more irregular than those of the rat,

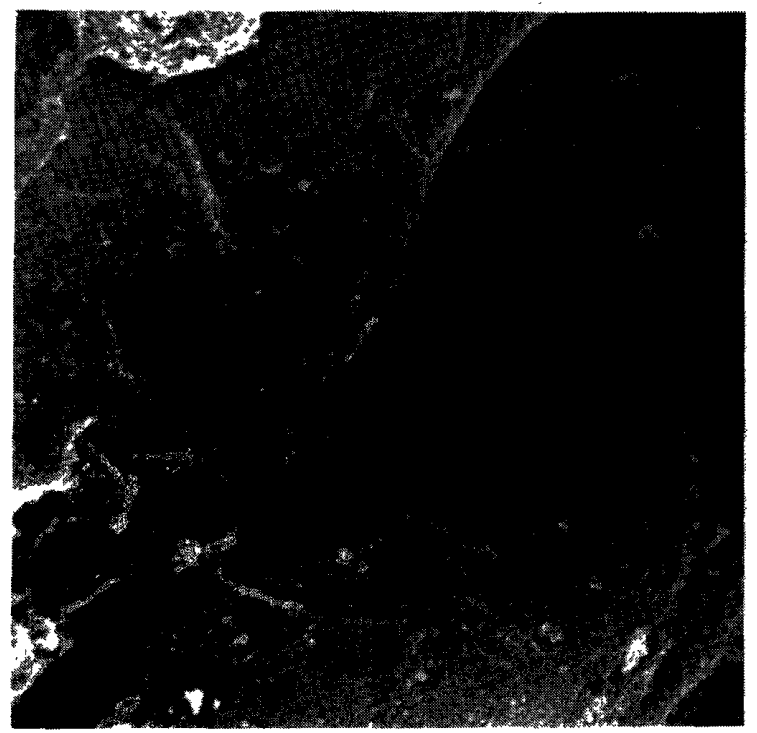

Fig. 14. Lateral processes of the endothelial cells of the cow. They do not meet with each other and extend to the outside of the endothelium. $\times 8,600$.

dog and cow (Figs. 13-16). In the horse, the sinus wall had a few irregularly distributed slits (Fig. 12). In the cat, the sinus wall had numerous slits largest in all the species examined (Fig. 17). Many erythrocytes were often observed to pass through the slits of the sinus wall to leave some blood cells attached to the slits. Macrophages with many projections entered into the lumen of the sinus through these slits (Figs. 12-18). The diameter of the slits was varied among the species examined.

The outer wall of the sinus was covered 


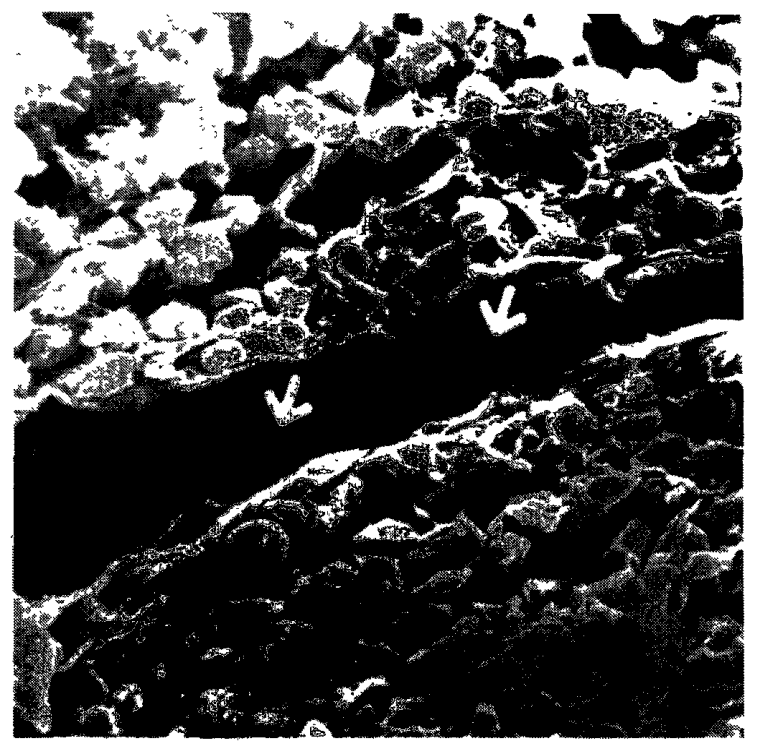

Fig. 15. Sinus of the pig. The endothelium consists of rod-shaped cells with lateral processes and has large slits (arrows). x1,200.



Fig. 17. Sinus of the cat. The sinus (S) in the red pulp is small and shorter than in any other species examined. The endothelium consists of flat stellate-shaped cells. Anastomosis and sheathed arteries (SA) are observed. $\times 260$.

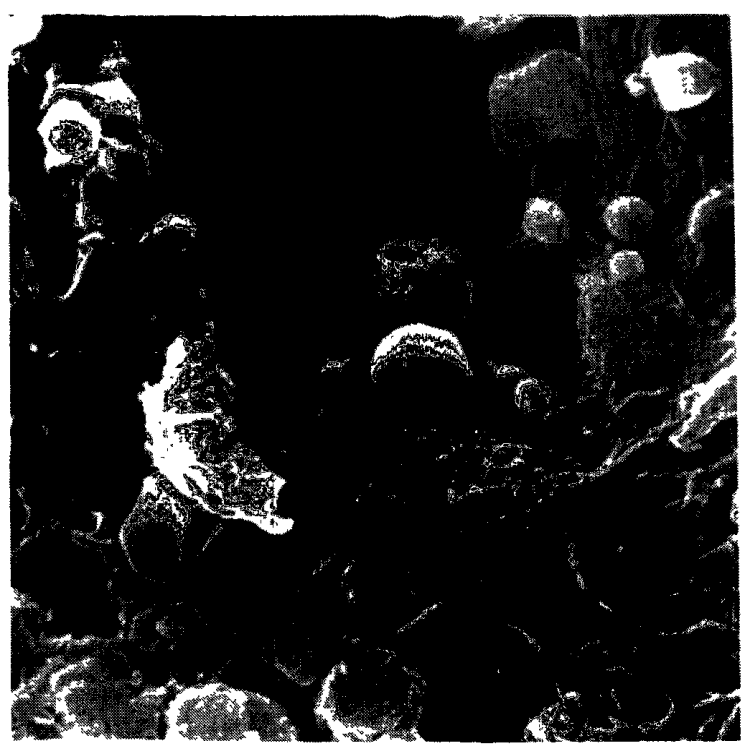

Fig. 16. Sinus of the pig. The endothelium consists of rod- and stellate-shaped cells, and has large slits. Blood cells are attached to the slits. $\times 3,000$.

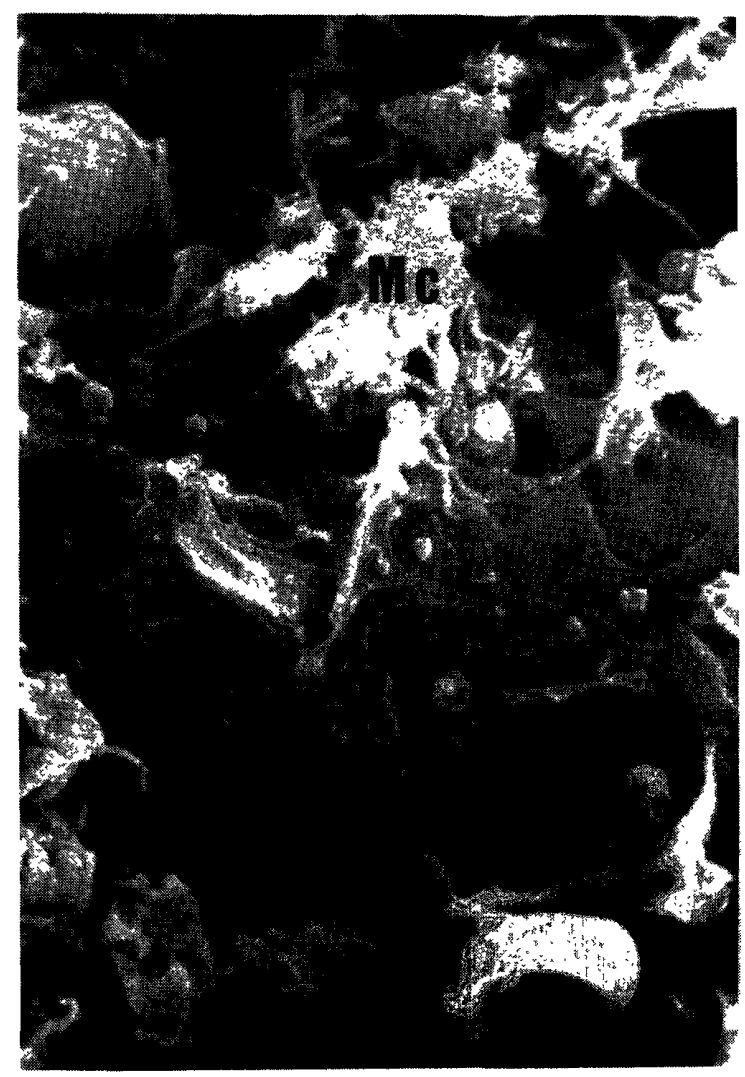

Fig. 18. The outer surface of the sinus wall in the cat. The pulp reticular cells touch on the wall, run across the long axis of the endothelium and make meshworks. The pores in the meshwork meet with the slits of the endothelium on the whole, but some do not meet completely. A macrophage (Mc) is attached to the slits. $\times 3,600$. 




Fig. 19. Sinus wall of the cow. The processes of the reticular cells ( $\mathrm{RC}$ ) touch on the outside of the endothelium and form corn- or foot-shaped ending. $\times 5,500$.

with the reticular cells of the splenic cord. The reticular cells were attached to the sinus wall by their processes ending as a foot-like expansion. The processes always overlapped on the outside of the endothelial cells, formed rings or bands arround the sinus, and constituted the meshworks in the rat and dog (Fig. 18). The processes of reticular cells of the splenic cords formed meshworks on the outside of the sinus wall in the cat, pig and horse (Figs. 15 and 16). Both band and foot-like processes were found in the cow (Fig. 19). The gap in the meshwork usually meet with the slits between the endothelial cells of the splenic sinus (Figs. 10, 18 and 19).

In the present study, the sinus wall in all species examined consisted of two layers of endothelial and reticular cells, the discontinuous basal lamina being intervened between the two layers (Figs. 13, 15-20).



Fig. 20. Transverse section of the sinus wall of the horse. It consists of endothelial cells (E), basal lamina (BL) and reticular cells (RC). Reticular fibers (RF) connect with the basal lamina. Free ribosomes and vesicles are observed in the endothelial cell. $\times 11,200$.

\section{DISCUSSION}

Sheathed artery: The wall of the sheathed artery was so far called as periarterial macrophage sheath (PAMS) [5], ellipsoid [7, 11, 36], Schweigger-Seidel sheath [36] or Kapillarenhülsen $[42,43]$. This structure was studied with light microscope by Billroth [2], Schweigger-Seidel [33] and others [3, 5, 17, $18,33,36,37,43,44]$. Although many reports have been published on the structure of the sheathed artery in cats, dogs and men by SEM and TEM, there have been only a few reports in the pig, horse and cow by scanning electron microscopy [30]. It was reported that sheathed arteries were not present in the rat spleen $[32,34]$.

The fine structure of the endothelial cells of 
the sheathed artery in the pig, horse and cow were reported to be almost the same as that in cats, dogs and men by light and electron microscopy $[5,7,12,36,42]$. Slits were not found between the endothelial cells of the capillary walls in the dog. Blue and Weiss [7] studied the contracted vascular bed of the dog spleen and observed slits and erythrocytes attached to the slits by transmission electron microscopy. Suzuki [38], using the modified method of perfusion, observed erythrocytes attached to the slits in the dog by scanning electron microscopy. According to the present study and the previous reports [5, $7,18,42]$, it is considered that the size of the slits of may change under various conditions.

Microfilaments. with a diameter of $10 \mathrm{~nm}$ or more were found in the endothelial cells of the cat, dog, pig, horse and cow. They are believed to be a part of cytoskeleton [31], but have only been reported in the cat, dog and horse $[5,7,11,42,48]$. In the present study, the filaments with a diameter of $10 \mathrm{~nm}$ were first described in the endothelial cells of the pig and cow.

Some investigators reported the phagocytosis of the reticular cells of the sheathed artery and the presence of macrophages in the reticular meshwork $[1,5,7,12,32,36]$. We think that the macrophages observed in meshwork came from the splenic cords when physiological changes such as an immunological response occured. Mechanical and biological functions were attributed to the sheathed arteries by Imai [18]. In the present study, it is suggested that the sheathed arteries may play a role as a filter to regulate the movement of blood cells because of the existence of slits and microfilaments.

Arterial capillary: In the present study, the structure of the arterial capillaries near the terminal portion was similar to that observed by many investigators $[15,19,20,23,38]$. The reticular cells and their processes attached on the outside of the arterial capillary held the capillaries in the splenic cords.
The termination of the arterial capillary in the dog was described as ampulla-shaped by Mall [24] and Thoma [40]. In the present study, the termination was sack-shaped in the dog. Ohta et al. [30] used cast specimens of the pig spleen, but failed to observe the form of the terminal portions. We also used cast specimens, and found the terminal portion to be sack-shaped in the pig. Hartwig [14] reported in the horse by light microscope that the terminal portion was ampulla-shaped and had small pores. Snook [34], also found terminal portions to be both ampulla- and funnel-shaped with sidepores in the horse and cow. In the present study, we found that the terminal portion was sack-shaped with sidepores in the horse and was funnel-shaped with some sidepores in the cow spleen. Termial portions in the dog, pig, horse and cow had sidepores or endpores, and blood cells in the terminal capillary were migrated into the splenic cords through slits. As the endothelium of the arterial capillary was not continuous with that of the sinus in these species, it was suggested to be open circulation system. Weiss [46] reported an open circulation system by observing crack specimens in the rat, while Murakami et al. [28] reported a closed circulation by observing the cast specimens. In the present study, it was demonstrated that the rat had both open and closed circulation. The present study also demonstrated that the termination of the arterial capillaries in the dog and cow showed a pattern of the "open but functional closed circulation" as reported by McCusky [25] and Suzuki [38] by electron microscopy.

Splenic sinus: Billroth [3] described the splenic sinus of the man with many slits and suggested it to be the beginning of the venous system. He called it the "cavernöse Milzvenen" or "cavernöse Milzvenensinus". Weidenreich [44] observed that the endothelium of the sinus was formed by longitudinally extended rod-shaped cells running parallel with each other to leave spaces between 
them, and that transverse reticular fibers (ring fibers) bound them together from the outside. However, Mollier [27] observed lateral processes between the rod-shaped cells, which Weidenreich [44] did not find, and termed them "protoplasmatischen". Many investigators $[6,8-10,26,34,38,41,42,47]$ studied the rat, rabbit, dog and human spleens and observed carefully the shape of the endothelial cells of these species. Snook [34] divided the animal spleens into "sinusal" and "non-sinusal". The sinusoids at the beginning of the splenic system were called primordial veins in the nonsinusal spleen, consisted of rod-shaped cells and never anastomosed with each other [13]. Hataba et al. [15] found the presence of anastomosing vasculatures in the mouse spleen, and used the term "sinus". Snook [34] used the term "primordial vein"'in his report on the mouse spleen. On the other hand, Blue and Weiss [6] used a term "venules" in the cat spleen instead of "primordial veins" of Snook [34].

In the present study, the shape of the endothelial cells of the sinus in the cat, pig and horse was considerably different from that in the rat, dog and cow. The basic structure of the endothelium of the sinus in the rat and dog were similar to that in the previous report on the rat, rabbit, dog and $\operatorname{man}[9,10,12,38,41,42,46]$. The two types of the endothelial cells, i.e. stellateand rod-shaped were seen in the pig. They changed their forms from stellate-shaped to rod-shaped. The cow spleen was also classified as non-sinusal according to Snook [34]. Although the shape of the endothelial cells of the cow was slightly different from the rodshaped cells of the rat and dog in the present study, it can be called rod-shaped. The lattice-like structure of the rod-shaped cells and anastomosing vasculature were also observed in the cow. The difference of the shape of the endothelial cells of the sinus among the species may suggest not only the physiological difference in the functions of the sinus or spleen, but also the embryological and phylogenetic difference in the development of the sinus or spleen.

The pulp reticular cells and their processes were attached on the sinus wall from the outside and made meshworks on the in all species examined. The side and number of slits between the endothelial cells were different from species to species. The function and relationship of the slits of the sinus wall and networks were unknown. These slits and meshworks may or may not meet together when the spleen contracts on distends. However, the fenestrations of the sinus wall may affect to the blood flow. When the blood cells pass through the sinus wall, the narrow slits of the wall are thought to squeeze the blood cells tightly to snap off the cytoplasm containing intraerythrocytic inclusions such as Heinz bodies or malaria plasmodia [10, 22, 47].

In all species examined in the present study, the sinus walls generally consist of endothelial cells, basal lamina and reticular cells of the splenic cords. But, it is unknown whether the blood cells migrate into the splenic cords or the sinus.

Anastomosis of the sinus was found in the spleen of the rat, cat, dog, pig, horse and cow. Endothelial cells were irregularly arranged in the anastomosing area. This may be related to the sphincter mechanism of the splenic sinus [26]. In addition to this sphincter mechanism, we think that the anastomosis of the sinus may play a similar role to that of the "tuberculum intervenosum" in the heart.

ACKNOWLEDGEMENTS. The authors would like to thank Dr. Yuh H. Nakanishi, Department of Veterinary Radiology, The College of Dairying, for his valuable advices, and to Mr. K. Iwasa, Mr. T. Hiraga, and Mr. K. Takehana, for their helpful discussions and encouragements.

\section{REFERENCES}

1. Aschof, L. 1926. Das reticulo-endotheliale System. Ergeb. Inn. Med. 26: 1-118. 
2. Billroth, T. 1857. Beiträge zur vergleichenden Histiologie der Milz. Arch. Anat. Physiol. 88: 88108.

3. Billroth, T. 1861. Zur normalen und pathologischen Anatomie der menschlichen Milz. Virchows Arch. Pathol. Anat. Physiol. Klin. Med. 20: 409425.

4. Björkman, S. E. 1947. The splenic circulation with special reference to the function of the spleen sinus wall. Acta Med. Scand. 128: 1-89.

5. Blue, J., and Weiss, L. 1981. Periarterial macrophage sheaths (ellipsoids) in cat spleen-An electron microscope study. Am. J. Anat. 161: 115134.

6. Blue, J., and Weiss, L. 1981. Vascular pathways in nonsinusal red pulp-An electron microscope study of the cat spleen. Am. J. Anat. 161: 135168.

7. Blue, J. and Weiss, L. 1981. Electron microscopy of the red pulp of the dog spleen including vascular arrangements, periarterial macrophage sheaths (ellipsoids) and the contractile, innervated reticular meshwork. Am. J. Anat. 161: 189-218.

8. Brown, E. M., and Dellman, H. D. 1981. Lymphatic system. pp. 176-186. In: Textbook of Veterinary Histology, 2nd ed. (Dellman, H. D., and Brown, E. M. eds.), Lea \& Febiger, Philadelphia.

9. Chen, L. T., and Weiss, L. 1972. Electron microscopy of the red pulp of human spleen. Am.J. Anat. 134: 425-458.

10. Chen, L. T., and Weiss, L. 1973. The role of the sinus wall in the passage of erythrocytes through the spleen. Blood 41: 529-537.

11. Dustin, P. 1957. Ultrastructure and function of the ellipsoids of the spleen. Their relationship with fat metabolism and red blood cells. Haematologica 60: 136-155.

12. Fujita, T. 1974. A scanning electron microscope study of the human spleen. Arch. Histol. Jpn. 37: 187-216.

13. Fukuta, K., Nishida, T., and Yasuda, M. 1969. Comparative and topographical anatomy of the fowl. LXIII. Structure and distribution of the fine blood vascular system in the spleen. Jpn.J. Vet. Sci. 31: 303-311. (in Japanese).

14. Hartwig, H. 1948. Die makroskopischen und mikroskopischen Merkmale und die Funktion der Pferdemilz in verschiedener Lebensaltern und bei verschiedenen Rassen. Z. Mikrosk. Anat. Forsch. 55: $287-410$.

15. Hataba, Y., Kirino, Y., and Suzuki, T. 1981. Scanning electron microscopic study of the red pulp of mouse spleen. J. Electron Microsc. 30: 46-56.

16. Helly, K. 1902. Zum Nachweise des geschlossenen Gefässsystems der Milz. Arch. Mikrosk.
Anat. Entw. -gesch. 59: 93-105.

17. Huech, W. 1928. Referat über die chronischen Milzvergrösserungen. Die normale menschliche Milz als Blutbehälter. Verh. Dtsch. Pathol. Ges. 23: 6-38.

18. Imai, T. 1954. Programs on the sheathed capillary in the spleen: mainly histological observations. pp. 60-86. In: Reports of Blood Discussion Association. 7th series, Nagai, Osaka. (in Japanese).

19. Irino, S., Murakami, T., and Fujita, T. 1977. Open circulation in the human spleen. Dissection scanning electron microscopy of conductivestained tissue and observation of resin vascular cast. Arch. Histol. Jpn. 40: 297-304.

20. Irino, S., Murakami, T., Fujita, T., Nagatani, T., and Kaneshige, T. 1978. Microdissection of tannin-osmium impregnated specimens in the scanning electron microscope: Demonstration of arterial terminals in human spleen. Scanning Electron Microsc. 11: 111-117.

21. Knisely, M. H. 1936. Spleen studies. I. Microscopic observations of the circulatory system of living unstimulated mammalian spleens. Anat. Rec. 65: 23-50.

22. Knisely, M. H. 1955. The microcirculation of the spleen of the mouse. Discussion. Angiology 6: 363-368.

23. MacNeal, W. J. 1928. The circulation of blood through the spleen pulp. Arch. Pathol. 7: 215227.

24. Mall, F. P. 1902-03. On the circulation through the pulp of the dog's spleen. Am. J. Anat. 2: 315-332.

25. McCuskey, P. S., and McCuskey, P. A. 1977. In vivo microscopy of the spleen. Bibl. Anat. 16: 121-125.

26. Miyoshi. M., Fujita, T., and Tokunaga, J. 1970. The red pulp of the rabbit spleen studied under the scanning electron microscope. Arch. Histol. Jpn. 32: 289-306.

27. Mollier, S. 1910-11. Über den Bau der capillaren Milzvenen (Milzsinus). Eine kritische Studie und eigene Beobachtungen. Arch. Mikrosk. Anat. 76: 608-657.

28. Murakami, T., Fujita, T., and Miyoshi, M. 1973. Closed circulation in the rat spleen as evidenced by scanning electron microscopy of vascular casts. Experientia 29: 1374-1375.

29. Murakami, T., Yamamoto, K., Itoshima, T., and Irino, S. 1977. Modified tannin-osmium conductive staining method for non-coated scanning electron microscope specimens. Its application to $\mathrm{mi}-$ crodissection scanning electron microscopy of the 'spleen. Arch. Histol. Jpn. 40: 35-40.

30. Ohta, Y., Tokioka, T., Okuda, H., and Suwa, F. 1977. A scanning electron microscopic study of the splenic sheathed vessel of the pig. Okajimas 
Folia Anat. Jpn. 54: 195-204.

31. Porter, K. R.. Byers. H. R.. and Ellisman, M. H. 1979. The cytoskeleton. pp. 703-722. In: The Neurosciences. Fourth Study Program (Schmitt, F. O., and Worden, F. G. eds.). The MIT Press Cambridge.

32. Raviola, E. 1975. Spleen. pp. 487-502. In: A Textbook of Histology, 10th ed. (Bloom, W., and Fawcett, D. W. eds.). W. B. Saunders, Philadelphia.

33. Schweigger-Seidel, F. 1862. Untersuchungen über die Milz. Virchows Arch. Pathol. Anat. Physiol. Klin. Med. 23: 526-570.

34. Snook, T. 1950. A comparative study of the vascular arrangements in mammalian spleens. $\mathrm{Am}$. J. Anat. 87: 31-77.

35. Snook, T. 1958. The histology of vascular terminations in the rabbit's spleen. Anat. Rec. 130: 711-729.

36. Solnitzky, O. 1937. The Schweigger-Seidel sheath (ellipsoid) of the spleen. Anat. Rec. 69: 55-75.

37. Staemmler, M. 1925. Die Bedeutung der Schweigger-Seidelschen Capillarhülsen der Milz. Virchows Arch. Pathol. Anat. Physiol. Klin. Med. 255: $585-598$.

38. Suzuki, T. 1982. Morphological approaches to the study of splenic terminal circulation. J. Jikei Med. Univ. 97: 1-22. (in Japanese).

39. Tanaka, K., and Nagatani, T. 1980. Scanning Electron Microscopic Atlas: Techniques for preparation in biological specimens. first ed., Asakura
Tokyo. (in Japanese).

40. Thoma, R. 1924. Der normale Blutstrom und die venose Stauung in der Milz. Virchows Arch. Pathol. Anat. Physiol. Klin. Med. 249: 100-117.

41. Thomas, C. E. 1967. An electron- and light-microscope study of sinus structure in perfused rabbit and dog spleens. Am. J. Anat. 120: 527-533.

42. Tischendorf, F. 1969. Die Milz. In: Handbuch der mikroskopischen Anatomie des Menschen (Möllendorff, W., and Bergman, W. eds.), SpringerVerlag, Berlin.

43. Watzka, M. 1937. Zur Kenntnis der Milz der Säugetiere. (Kapillarhülsen: Megakaryocyten. Sinusendothel und Plasmaabbau). Z. Mikrosk. Anat. Forsch. 41: 498-524.

44. Weidenreich, F. 1901. Das Gefässsystem der menschlichen Milz. Arch. Microsk. Anat. 58: 247-376.

45. Weiss, L. 1962. The structure of fine splenic arterial vessels in relation to hemoconcentration and red cell destruction. Am. J. Anat. 111: 131179.

46. Weiss, L. 1974. A scanning electron microscopic study of the spleen. Blood 43: 665-691.

47. Weiss, L. 1977. The spleen. pp. 545-573. In: Histology, 4th ed. (Weiss, L., and Greep, R. C. eds.). McGraw-Hill, New York.

48. Zwillenberg, L. O., and Zwillenberg, H. L. 1963. Zur Strukture und Funktion der Hülsencapillaren in der Milz. Z. Zellforsch. Mikrosk. Anat. 59: 908-921.

要 約

走查電子顕微鏡によるラット，ネコ，イヌブタ，ウマ扣よびウシ脾蔵の微細血管系の比較形態学：関 あず さ・阿部光雄（酪農学園大学獣医学科）—ラット，ネコ, イヌ, ブタ, ウマおよびウシの脾臓荻動脈, 動脈性 毛細血管および脾洞を走查電顕と透過型電顕を用いて観察した。荻動脈は杆状形の内皮細胞からなる毛細血管 と，これを囲む細網細胞からなっていた。萊の網眼中には血小板や赤血球が観察されたが，イ又を除いては白血 球や大食細胞は見られなかった。ラットでは苏動脈を欠いていた。イヌを除くすべての動物で内皮細胞間偪直径 1 3 $\mu \mathrm{m}$ の間隙が観察された。ラット，イヌ，ブタおよびウマの動脈性毛細血管の終末部は翼状で，ウシでは漏 斗状を呈し，すへてての動物で終末孔もしくは側孔が見られ，脾索腔と通じていた。ラットでは，いくつかの動脈 終末部か脾索に開放し，あるものは直接脾洞に続いていた。脾洞内皮細胞の形はラット，イヌおよびウシでは杆 状，ネコとウマでは平たい星形を呈し，ブタでは両形がみられた。これらの脾洞壁には血球や大食細胞が脾洞か ら脾索へ，もしくは，その逆に移動する間隙があった。脾洞内皮細胞の外側には細網細胞が付着していた。 